\title{
Deconstructing the concept of renewable energy-based mini-grids for rural electrification in East Africa
}

\section{Pedersen, Mathilde Brix}

Published in:

Wiley Interdisciplinary Reviews : Energy and Environment

Link to article, DOI:

10.1002/wene.205

Publication date:

2016

Document Version

Peer reviewed version

Link back to DTU Orbit

Citation $(A P A)$ :

Pedersen, M. B. (2016). Deconstructing the concept of renewable energy-based mini-grids for rural electrification in East Africa. Wiley Interdisciplinary Reviews : Energy and Environment, 5(5), 570-587. https://doi.org/10.1002/wene.205

\section{General rights}

Copyright and moral rights for the publications made accessible in the public portal are retained by the authors and/or other copyright owners and it is a condition of accessing publications that users recognise and abide by the legal requirements associated with these rights.

- Users may download and print one copy of any publication from the public portal for the purpose of private study or research.

- You may not further distribute the material or use it for any profit-making activity or commercial gain

- You may freely distribute the URL identifying the publication in the public portal

If you believe that this document breaches copyright please contact us providing details, and we will remove access to the work immediately and investigate your claim. 


\title{
Title: Deconstructing the concept of renewable energy-based mini-grids for rural electrification in East Africa
}

\author{
Author: Mathilde Brix Pedersen
}

Affiliation: UNEP DTU Partnership, DTU Management Engineering, UN City, Marmorvej 51, 2100 Copenhagen, Denmark, brix@dtu.dk, +45 45335326

\begin{abstract}
The goal of providing universal energy access to all by 2030 under the UN-led SE4ALL initiative calls for new and innovative solutions to rural electrification and is fuelling the recent interest in mini-grids. Mini-grid solutions are emerging as a third alternative to rural electrification, coming between the option of large-scale grid extension and pico-scale stand-alone solutions like solar home systems (SHS) or solar lanterns.

International expectations of mini-grids are high, with the International Energy Agency suggesting that they will play a significant role in reaching the goal of universal access. Based on a detailed review of past, ongoing and planned mini-grids in East Africa, this paper seeks to deconstructs the popular notion of mini-grids for rural electrification in East-Africa. The paper reveals that so far activities carried out under the heading of mini-grids to a large extent consist of the hybridisation of existing utility-owned electricity systems for medium-size towns located far from the grid, which does not necessarily contribute to rural electrification. On the other hand, limited but increasing activity is identified regarding the use of mini-grids to bring electricity to rural villages and smaller rural towns. This is of specific interest because it is for this type of mini-grid that the main challenges are to be found with respect to identifying and testing adequate financing, ownership and business models. Based on the trajectories identified for mini-grids for rural electrification and the challenges identified in the literature, the paper concludes by proposing three avenues for further research.
\end{abstract}

Keywords: mini-grid, Tanzania, Uganda, Kenya, deconstruction, ownership models 


\section{Introduction}

Attention to mini-grids as a way of accelerating energy access in unserved rural areas has grown rapidly in the past few years. With the announcement of "the international year of sustainable energy for all" (SE4ALL) by the UN Secretary General in 2012, the issue of energy poverty was raised high on the international development agenda. Although the issue of energy poverty is not new and has been recognised by governments and development agencies for decades, the SE4ALL initiative is the first time the issue has been addressed in a coordinated manner. The goal of universal access to all by 2030 under the SE4ALL initiative calls for new and innovative solutions and is fuelling the recent interest in mini-grids.

Mini-grid solutions are emerging as a third alternative to rural electrification, coming between the option of large-scale grid extension and pico-scale stand-alone solutions like solar home systems (SHS) or solar lanterns. The International Energy Agency (IEA) suggests that $70 \%$ of all rural areas globally are not suited to electrification through grid extension, and that renewable energy-powered mini-grids will therefore play a significant role in reaching the goal of universal access ${ }^{1}$. At the same time, there are strongly voiced expectations that the private sector will play a major role in upscaling mini-grids in respect of both financing and implementation.

Expectations regarding mini-grids are based partly on an indispensable need for alternative solutions to slowly growing national grids and the low-quality options of individual solutions, and partly on a highly positive narrative about their advantages. Characteristics such as greater flexibility than the main grid, modularity and better quality electricity than individual systems are emphasised. Furthermore, recent technological advances, especially in solar PV, and the resulting lower prices, greater efficiency and greater reliability have led to a situation in which renewable energy-based mini-grids are costcompetitive with other decentralised electrification solutions like diesel generators ${ }^{2,3}$. Finally, the possibility of grid-readiness and smart solutions drawing on information and communication technology provide promise of new opportunities for both mini-grid developers and rural consumers.

However, the concept of mini-grids in the current international development discourse is a highly popular notion without a commonly adopted conceptualisation of the large variety of systems. The positive narrative of mini-grids has developed a considerable degree of international hype, with mini-grids being put forward almost as a panacea for fulfilling the SE4ALL goal of universal access by practitioners and researchers. As highlighted by ARE, mini-grids "have the potential to become the most powerful technological approach for accelerated rural electrification" (Reference 3, p.11).

In Asia the mini-grid experience is fairly well-documented, particularly in India, with a growing body of literature documenting operational experience (case studies and lessons learnt) with mini-grids. Topics in the literature include: i) reviewing current experience from the angle of technology, business models, policies, financing and opportunities and challenges ${ }^{4-7}$; ii) evaluation of the impact of mini-grids on rural electrification ${ }^{8,9}$; iii) comparative analysis of specific organisational mini-grid models ${ }^{10}$; and iv) analysis of specific mini-grid systems from the angle of economic viability ${ }^{11}$, household preferences ${ }^{12}$ and socio-economic aspects ${ }^{13}$. Studies using specific theoretical lenses such as transitions theory ${ }^{14,15}$ are also emerging.

Turning to Africa the literature is mainly addressing rural electrification in general. Topics in the literature include: i) generic business models ${ }^{16,17}$; ii) country specific case studies ${ }^{18}$; iii) policy-tailored analyses targeting country-scale institutional environment and enabling frameworks ${ }^{19-22}$; iv) financing ${ }^{23,24}$; and v) planning and scale ${ }^{25-27}$. 
But interestingly, on the continent where the challenges of achieving universal access are the greatest, only limited research has been carried out on practical experience with renewables-based mini-grids for rural electrification ${ }^{10}$. Three pieces of work, all projectspecific single-case studies using a narrative style to describe the organisational arrangement of the mini-grid, are highlighted here. Ilskog et al. describe an organisational model of a mini-grid in Tanzania where a cooperative owns and manages the system ${ }^{28}$. Eder et al. describe a particular mini-grid project in Uganda through a technological innovation system lens ${ }^{29}$, while Kirubi et al. evaluate to what extent a specific mini-grid project contributes to rural development ${ }^{30}$. There is thus a need to understand current trends in mini-grid development in an African context and to set a relevant research agenda.

Against this background, this paper sets out to answer to the following research questions:

- How is the concept of the mini-grid understood and used in the current international development discourse?

- What are the status and current trends in the application of organisation models for renewable energy mini-grids in East Africa?

- What are the implications for setting a relevant research agenda?

The paper is structured as follows. Section 2 presents the research methods. Section 3 presents a framework for deconstructing the concept of mini-grids. Section 4 maps existing mini-grids in Kenya, Uganda and Tanzania according to this framework and highlights country priorities and directions. Section 5 provides a discussion of identified trends and concludes by providing suggestions for further research.

\section{Methods}

The paper is based on a desk study comprising a review of peer-reviewed and grey literature supplemented by information retrieved from the internet from mini-grid developers, development agencies, governments and NGOs.

The mini-grid types in Section 3.1 are derived inductively from the available information on mini-grid cases described in the literature. Ownership models in Section 3.2, on the other hand, are based on an already well-established categorisation of ownership structures in the literature.

In addition to the above-mentioned sources, to identify existing mini-grids systems in Tanzania, Uganda and Kenya in Section 3, information was gathered through participation in the Africa Mini-grid Summit held in Nairobi on 18-19 November 2014. In addition, email correspondence with mini-grid developers has been used as a source of confirmation and elaboration and of snowballing to reach further informants.

\section{Analytical framework}

The aim of this section is to deconstruct the popular notion of mini-grids in order to arrive at an empirically based conceptualisation of mini-grids broken down into sub-categories.

Definitions of mini-grids in the literature range very broadly. Some definitions are allencompassing, with no defined size limit and with the only defining characteristic being an off-grid generation and distribution system ${ }^{31-33}$. Other authors use the defining characteristic of size and define mini-grids to be in the capacity range of $5 \mathrm{~kW}$ to $200 \mathrm{~kW}{ }^{14}$ or up to 300 $\mathrm{kW}^{34}$. Schnitzer et al. uses the term micro-grids, which they define as "systems up to 
roughly $100 \mathrm{kW"}{ }^{10}$. Tenenbaum et al. also distinguish between micro- and mini-grids and use targeted markets as a defining characteristic, mini-grids being "isolated grids (typically ranging in power output from tens of kilowatts $(\mathrm{kW})$ to tens of megawatts (MW) and serving several hundred customers) in rural areas of developing countries", while micro-grids are "systems of very small scale, with power output ranging from hundreds of watts to a few kilowatts, and typically fewer than 150 household customers" 35 ( p. 44). Yet others include the term pico-grid to describe systems below $1 \mathrm{~kW}^{36}$. UNEP, in its "Clean Energy Hybrid Mini-Grids in Remote Areas: An Investment Opportunity?" programme uses "sufficient scale for investment" in defining mini-grids for inclusion in the programme and focuses on systems $>100 \mathrm{~kW}^{37}$.

These various definitions point to different perceptions of what a mini-grid is and what the concept entails. In the context of the goal of universal access to energy, a broad definition of mini-grids encompassing all mini-grid types could be appropriate to some extent, as all mini-grids are likely to create positive social impacts in the form of general increases in electrification. However, too broad a definition also masks the fact that some mini-grids are implemented in order to provide energy access directly benefitting rural poor populations, whereas other mini-grids are implemented in order to increase energy supply in urban or periurban settings without increasing rural energy access. Business models in pursuit of these different aims are bound to differ, with one end of the spectrum targeting rural populations and requiring long-term and less financially lucrative investments, while the other end of the spectrum depends on easier, quicker and more financially profitable opportunities targeting broader segments of society. Furthermore, a broad definition also masks the fact that different policy frameworks and financing mechanisms are needed to promote different types of minigrids and business models. Against this background, an attempt is made in Section 3.1 to deconstruct the concept of mini-grids to arrive at more detailed categorisation of them.

\subsection{Mini-grid types}

Table 1 presents an overview of the different methods of rural electrification, with mini-grids placed in the spectrum between pico-sized household systems and large-scale grid extension. Rural electrification is divided into four overall categories according to the systems used: off-grid household systems, off-grid stand-alone systems, mini-grids and grid extension. These four categories are further divided into a sub-system typology which makes it possible to differentiate between various mini-grid types.

Mini-grids as presented in Table 1 are defined as decentralised energy systems consisting of power generation assets (hydro turbine, solar panels, batteries, inverters, etc.) and distribution assets (the wires, poles etc.) with power capacity between 0,2 kW and $2 \mathrm{MW}$ connecting two or more individual households. This definition covers the majority of systems called mini-grids in the literature. The three characteristic features of mini-grid sub-systems are: i) the nature of the power supply (AC/DC); ii) the targeted market; and iii) the size of the system. Mini-grids are divided into the following four sub-systems: "DC village mini-grids", "ABC mini-grids", "AC village mini-grids" and "Large mini-grids". The characteristics and definitions of these four mini-grid types will be described in detail below.

The classification in Table 1 is not assumed to be definitive or exhaustive, and the various electrification systems listed may overlap between the various categories. However, the table is meant to situate mini-grids in the wider context of rural electrification alternatives and to present a breakdown and hence a better overview of the mini-grid alternatives currently identified in the literature. 
Table 1. Characteristics of electrification methods

\begin{tabular}{|c|c|c|c|c|}
\hline $\begin{array}{l}\text { Rural } \\
\text { electrification } \\
\text { system }\end{array}$ & Sub-system & $\begin{array}{l}\text { Nature of } \\
\text { power } \\
\text { supply }\end{array}$ & Market Description & $\begin{array}{l}\text { Capacity / } \\
\text { approximate } \\
\text { size }^{*}\end{array}$ \\
\hline \multirow[t]{2}{*}{$\begin{array}{l}\text { Off-grid } \\
\text { household } \\
\text { systems }\end{array}$} & $\begin{array}{l}\text { Small pico-systems: solar } \\
\text { lanterns, LED lamps, solar } \\
\text { chargers }\end{array}$ & DC & $\begin{array}{l}\text { Lighting and charging of batteries and } \\
\text { mobile phones in mainly non-electrified } \\
\text { areas }\end{array}$ & $1-10 W$ \\
\hline & Home systems (e.g. SHS) & DC & $\begin{array}{l}\text { Off-grid electricity demand in private } \\
\text { homes in dispersed settlements, in } \\
\text { smaller non-electrified villages and on } \\
\text { the outskirts of electrified towns and } \\
\text { villages far from existing distribution lines }\end{array}$ & $10-100 \mathrm{~W}$ \\
\hline $\begin{array}{l}\text { Non-household } \\
\text { stand-alone off- } \\
\text { grid systems }\end{array}$ & $\begin{array}{l}\text { Stand-alone 'institutional } \\
\text { systems' }\end{array}$ & $\mathrm{AC}$ & $\begin{array}{l}\text { Institutions located in villages without } \\
\text { grid or mini-grid, or on the outskirts of } \\
\text { grid-electrified villages and basic } \\
\text { electricity supply for the tourism sector } \\
\text { (mainly lighting) for rural lodges and } \\
\text { hotels }\end{array}$ & $50-500 W$ \\
\hline \multirow[t]{4}{*}{ Mini-grids } & $\begin{array}{l}\text { DC village mini-grids (e.g. } \\
\text { modular PV systems). Also } \\
\text { referred to as micro-grids by } \\
\text { some. }\end{array}$ & DC & $\begin{array}{l}\text { Single village (up to hundreds of } \mathrm{HH} \text { ) } \\
\text { located far from existing grid }\end{array}$ & $0.2-5 \mathrm{~kW}$ \\
\hline & $\begin{array}{l}\text { Anchor-business-community } \\
\text { (ABC) mini-grids (e.g. } \\
\text { telecom towers or lodges) }\end{array}$ & $\mathrm{AC}$ & $\begin{array}{l}\text { Powering an anchor costumer, combined } \\
\text { with supply to nearby villages }\end{array}$ & $0.2-15 \mathrm{~kW}$ \\
\hline & $\begin{array}{l}\text { AC village mini-grids (e.g. } \\
\text { hybrid PV-diesel, hydro } \\
\text { schemes) }\end{array}$ & $\mathrm{AC}$ & $\begin{array}{l}\text { Single or plural villages (up to hundreds } \\
\text { of } \mathrm{HH} \text { ) and small towns located far from } \\
\text { existing grid }\end{array}$ & $1-300 \mathrm{~kW}$ \\
\hline & $\begin{array}{l}\text { Large mini-grids (e.g. diesel } \\
\text { powered) }\end{array}$ & $\mathrm{AC}$ & Large towns located far from existing grid & $\begin{array}{l}>300 \mathrm{~kW}-2 \\
\mathrm{MW}\end{array}$ \\
\hline \multirow[t]{3}{*}{$\begin{array}{l}\text { Grid-connected } \\
\text { mini-grids }\end{array}$} & $\begin{array}{l}\text { SWER (single wire earth } \\
\text { return) }\end{array}$ & $\mathrm{AC}$ & $\begin{array}{l}\text { SWER connection to private and } \\
\text { cooperative owned mini-grid }\end{array}$ & $0.2-500 \mathrm{~kW}$ \\
\hline & $\begin{array}{l}\text { Agro-business (a larger } \\
\text { version of the } A B C \text { mini- } \\
\text { grid) }\end{array}$ & $\mathrm{AC}$ & $\begin{array}{l}\text { Own generation combined with whole } \\
\text { sale to utility (sometimes also combined } \\
\text { with distribution to local community) }\end{array}$ & $1-5 \mathrm{MW}$ \\
\hline & $\begin{array}{l}\text { Connection of existing mini- } \\
\text { grid }\end{array}$ & $\mathrm{AC}$ & $\begin{array}{l}\text { Any of the above (except DC Village mini- } \\
\text { grid) }\end{array}$ & $\begin{array}{l}0.2 \mathrm{~kW}-5 \\
\mathrm{MW}\end{array}$ \\
\hline Grid-extension & Electricity generation & $\mathrm{AC}$ & $\begin{array}{l}\text { Expansion of production capacity in } \\
\text { existing grid }\end{array}$ & $>4 \mathrm{MW}$ \\
\hline
\end{tabular}

Source: adapted from ${ }^{38}$.

\footnotetext{
* Terminology in regards to capacity differs depending on technology. For solar PV technology, as maximum electric load depends on solar irradiation levels and therefore cannot be expected at all times, kW or MW peak (p) is used to describe the potential maximum capacity. For other technologies, such as diesel or biomass generators, $\mathrm{kW}$ or MW is used for the maximum load, which in this case can be delivered at any time. In this paper, $\mathrm{kW}$ and MW are used as maximum load for all mini-grid systems regardless of technology.
} 


\section{DC village mini-grids $(0.2$ - $5 \mathrm{~kW})$}

The "DC village mini-grid" provides DC power at a low voltage of between 12 and 48 $\mathrm{V}$ and for a limited number of hours, usually $5-7^{5}$. The DC village mini-grid system consists of a DC power-generating unit (e.g. one or more solar PV panels), wires for distribution, a control unit and an electrical storage unit ${ }^{39}$. As the name suggests, the DC village mini-grid supplies power to a village (or a cluster of villages), the off-takers of electricity being people living in the village either for private use or for low-voltage appliances in shops. The DC village mini-grid can supply power for appliances like LED lighting, cell phone charging, radios and DC TVs or fridges. The sizes of DC village mini-grids range from about $0.2 \mathrm{~kW}$ to about $5 \mathrm{~kW}$.

DC village mini-grids provide power that is comparable to pico-systems like SHS and cannot support productive uses to the same extent as AC-driven systems. DC village minigrids can, however, provide cheap and reliable power in areas where the main demand is for lighting and mobile phone charging. Due to the restricted applicability of DC power, some authors refer to DC village mini-grids as micro-grids ${ }^{7}$ or as skinny-grids ${ }^{40}$.

\section{Anchor-Business-Customers (ABC) mini-grids (0.2 - 15 kW)}

The Anchor-Business-Customers mini-grid supplies power to three different groups of targeted customers, namely an anchor client, who is ensuring a steady revenue for the developer; small village businesses or institutions with a greater load demand than regular households; and lastly rural household customers ${ }^{41}$. ABC mini-grids supply AC power through an AC low-voltage network (e.g. 230V/50Hz, 120V/60Hz). The system consists of a generating unit, distribution wires, storage unit, load controller and inverter. The heart of the AC-coupled system is the bi-directional battery inverter, which provides the voltage and frequency control of the grid ${ }^{42}$. The size of ABC mini-grids are between 0.2 and $15 \mathrm{~kW}^{38}$.

Currently the ABC mini-grid is associated particularly with the telecoms sector and greening of the current diesel-fired generators used to electrify remote mobile masts. Implementation of ABC mini-grids is driven primarily by cost savings potentials for power delivery companies, as solar PV-driven power stations for telecom base stations are increasingly competitive with conventional diesel-driven ones ${ }^{43}$.

\section{AC village mini-grid (1 - $300 \mathrm{~kW})$}

The technical specifications of an AC village mini-grid are the same as those of $A B C$ mini-grids. Like the DC village mini-grid, the AC village mini-grid supplies power to people living in rural villages as well as local businesses, however without an anchor customer. The defined target market is hence a whole village, a subgroup in a village or a cluster of villages. Systems are of sizes between $1 \mathrm{~kW}$ and $300 \mathrm{~kW}$, with the upper limit being highly indicative.

AC village mini-grids have the potential to deliver three-phased grid-quality power with high reliability. They can power high-power devices such as fans, agricultural machines, pumps etc. and can thus support productive uses. Furthermore they can be designed to be grid-ready, which means that they can be integrated into the national grid in the case it arrives at the location. However, there are no standards for mini-grid systems, and AC village minigrids are built according to individual specifications. Accordingly, AC village mini-grids are not necessarily designed to provide three-phased power or to be grid-ready.

\section{Large mini-grid (> $300 \mathrm{~kW}-2 \mathrm{MW})$}

Large mini-grids differ from AC village mini-grids in having a higher installed capacity, otherwise the technical components are the same. Mini-grids of this type usually range above $300 \mathrm{~kW}$ up to several MW. However the limit between AC village mini-grids 
and large ones is somewhat arbitrary, and when tested empirically it can prove difficult in some cases to distinguish AC village grids from large mini-grids solely on the basis of capacity size. However, instead of being targeted at the rural population on the village scale, large mini-grids are targeted at urban centres located far from the main grid or at powering a factory or large agribusiness.

In Africa, large mini-grids have traditionally been installed by the utility as a supplement to ongoing grid-extension, simply as a least-cost option for electrifying urban centres lying out of the reach of the main grid. Large agribusinesses that produce electricity for their own consumption and supply power to nearby communities are also examples of large mini-grids.

\subsection{Ownership models}

A second dimension by which to categorise mini-grid systems, is according to the organisational model. Ownership of the assets, responsibility for implementation, responsibility for operation and maintenance (O\&M) and financing the system all form part of the organisational model for implementing and running a mini-grid ${ }^{3}$. These four aspects can be divided between various actors in complex ways, which makes the definition and classification of such organisational models challenging.

In the effort to define and classify organisational models, some authors refer to business models ${ }^{3}$, other to operator models ${ }^{41}$ and yet others to ownership models ${ }^{44}$. According to ARE, "ownership is clearly the dominant and most decisive element on which to base a typology of business models" (Reference 3, p. 21). However, as Hazelton et al. has pointed out, the term "ownership" is interpreted differently in the literature ${ }^{45}$. Some authors define the owner of a mini-grid "as the entity that initiates the project and finances its delivery [...]" (Reference 45, p. 2). Other interpretations of ownership include those responsible for the operation and maintenance of the system (ibid.) (E.g. ${ }^{41}$ ).

In order to establish a clear defining parameter on which to classify organisational models, this paper defines ownership models based on actual and legal ownership of assets. The focus on legal ownership has been chosen to make a clear distinction between who owns, implements, operates and finances the mini-grid. It is argued here that actual ownership of assets deserves more attention than it currently receives, and that legal ownership can serve as a more accurate parameter when categorising organisational models.

The four ownership models adopted here are the following: utility ownership, hybrid ownership (a combination of private/utility/community), private ownership and community ownership ${ }^{3,41}$.

Particularly in relation to community ownership, a clearer distinction between the four aspects of an organisational model could prove valuable, as the current terminology on community ownership is vague. The term "community ownership" is used in the literature to refer to a wide variety of organisational models, including arrangements in which legal ownership does not lie with the community ${ }^{17,46,47}$. The term "ownership" is hence used in a broad sense to describe both legal ownership, i.e. cooperatives ${ }^{48,49}$, and to describe a sense of ownership in the meaning of a local buy-in. This paper therefore suggests that the specific terminology of community ownership be broadened to adopt a new term that covers the specific type of community ownership in the meaning of local buy-in, namely "symbolic ownership". In the classification below, community ownership is thus further subdivided into legal ownership and "symbolic" ownership. 
Ownership of assets does not determine the responsibility for operation and management (O\&M) nor for the financing of the system. These aspects therefore have to be elaborated separately under each ownership model. Each of the four ownership models can depend on one or more of the contractual arrangements highlighted below in Table 2 in relation to O\&M, commercial risk and capital investment.

Table 2. Contractual options for the four ownership types

\begin{tabular}{|l|l|l|l|l|}
\hline $\begin{array}{l}\text { Contractual } \\
\text { arrangements }\end{array}$ & $\begin{array}{l}\text { Operation and } \\
\text { Maintenance }\end{array}$ & $\begin{array}{l}\text { Commercial } \\
\text { Risk }\end{array}$ & $\begin{array}{l}\text { Capital } \\
\text { Investment }\end{array}$ & $\begin{array}{l}\text { Contract } \\
\text { Duration }\end{array}$ \\
\hline None & Owner & Owner & Owner & N/A \\
\hline Outsourcing & 3rd party & Owner & Owner & 1 to 2 years \\
\hline $\begin{array}{l}\text { Management } \\
\text { contract }\end{array}$ & 3rd party & Owner & Owner & 3 to 5 years \\
\hline $\begin{array}{l}\text { Long-term } \\
\text { lease }\end{array}$ & 3rd party & 3rd party & Owner & 8 to 15 years \\
\hline Concession & 3rd party & 3rd party & 3rd party & 25 to 30 years \\
\hline $\begin{array}{l}\text { Build, Operate } \\
\text { Transfer }\end{array}$ & 3rd party & 3rd party & Owner & 20 to 30 years \\
\hline $\begin{array}{l}\text { Build, Own, } \\
\text { Operate, } \\
\text { Transfer }\end{array}$ & 3rd party & 3rd party & 3rd party & 20 to 30 years \\
\hline
\end{tabular}

Source: adapted from ${ }^{50}$

The most typical combinations of ownership model and contractual options are elaborated further below.

\section{Utility Ownership}

Utility ownership is where a utility owns both generation and distribution assets. $\mathrm{O} \& \mathrm{M}$ and financing can be split between public and private entities in various ways. These organisational arrangements take the form of public private partnerships (PPP) with different contractual arrangements. PPP contracts include service contracts, management contracts or long-term leases. With a service contract, the public entity remains the primary service supplier, but sub-contracts specific activities to a third-party operator. This can include some of the functions of O\&M. Commercial risk and capital investment lie with the public entity. A management contract between a public entity and a private entity will usually cover all the functions of O\&M, as well as several management functions, such as equipment management, staff management, accounting or marketing services ${ }^{50}$. Also here, commercial risk and capital investment lie with the public entity. An example of a management contract between a public entity and a private entity is the Santo Antâo Island solar PV hybrid minigrid in Cape Verde ${ }^{51}$. Through a long-term lease, the commercial risk is transferred to a private entity. Under such a contract the contractor agrees to manage a public service, at his own risk, for a consideration paid by consumers ${ }^{50}$. An example of a long-term lease is the SPUG project in the Philippines ${ }^{3}$.

\section{Hybrid Ownership}

Hybrid ownership is where ownership of generation assets and distribution assets is divided between two or more entities. In this model, specific contractual arrangements between different actors apply. The most common of such arrangements is the power purchase agreement (PPA), in which a small power producer who owns the production assets sells power to a distributor who owns the distribution network, usually the utility. O\&M and the 
financing of such systems are usually also hybridized in nature. For example, in a Build, Operate and Transfer Contract, investment charges, operation and maintenance, commercial risk and asset ownership for the duration of the contract are shared between the public and private entities as part of a mixed enterprise corporation ${ }^{50}$. An example of hybrid ownership is the Tanganyika Wattle Company Ltd (TANWAT) in Tanzania, which, in addition to generating power for its own consumption, also sells power through a PPA to a national utility-owned mini-grid ${ }^{52}$.

\section{Private Ownership}

Private ownership refers to cases in which a private entity plans, builds and owns both production and generation assets. Funding depends on private equity and commercial loans, as well as, in some cases, on some form of government support, e.g. grants, subsidies, resultsbased financing, or public-sector loan guarantees ${ }^{41}$. Fully privately financed mini-grids are rare but do exist (e.g. Powergen and Powerhive in Kenya, Mesh Power in Rwanda and India). O\&M usually lies with the private business itself, but it can also be outsourced to a third party. O\&M is in some cases handed over to a community-based organisation in order to increase local buy-in and the local "sense of ownership". This particular arrangement is referred to in this paper as "symbolic" community ownership and is elaborated further below. A private company can also Build, Own, Operate and later Transfer ownership (BOOT) to, e.g., a local cooperative or village group. An example of this is DESI Power in India ${ }^{11}$. In the case of the concession, investment charges, operation and maintenance, commercial risk and asset ownership for the duration of the contract are fully born by a private contractor. An example of privately owned mini-grids being operated through a concession is the Yeelen Kura solar hybrid mini-grid in Mali ${ }^{51}$.

\section{Community Ownership}

In an attempt to add clarity to the terminology on community ownership, I distinguish in this paper between legal ownership and "symbolic" ownership. Legal ownership entails full ownership by a communal institutional entity (e.g. a cooperative) of production and distribution assets. O\&M activities can be outsourced to a third party or remain with the owner (the communal institutional entity). Examples include Thiba in Kenya ${ }^{53}$ and Urambo in Tanzania ${ }^{49}$. In these cases, financing usually comes from donors and implementation support from NGOs or REAs.

"Symbolic" community ownership entails an institutional arrangement whereby legal ownership of the assets remains with the implementer or the investor, whether an NGO, a private company, REA or municipal utility, whereas "symbolic" ownership is transferred to the community through the formation of, e.g., an energy committee, which then owns responsibility for the O\&M of the system. Especially in relation to community ownership, ownership structures are often so vaguely described in the literature that it is difficult to describe the institutional arrangements involved. Therefore the prevalence of symbolic ownership is unknown, and more research will be needed to understand what role this ownership type plays in the field of what the literature refers to as community-based minigrids. 


\section{Current and planned mini-grid installations in East Africa}

Section 4.1 provides an overview of currently operating mini-grids in Tanzania, Uganda and Kenya based on the framework outlined in Section 3 and provides an overview of the policy environment and planned mini-grids in the tree countries (Section 4.2). This will be followed by a discussion of identified trends in the market in Section 5.

\subsection{Current mini-grid installations}

Due to the limited availability of information on organisational models and ownership models, this section does not claim to be exhaustive. However, it presents a broad and inclusive picture of the current mini-grid landscape in East Africa illustrated by examples of mini-grid types and ownership models in the region. These examples of currently operating mini-grids are presented in

based on the classification in Section 3 and are organised according to ownership model, type of mini-grid and country.

Utility-owned mini-grids are left out of this table, as they represent primarily "large minigrids" and have traditionally been implemented with the primary function of electrifying large towns or cities. For that reason it can be argued that their role in rural electrification is limited.

Table 3. Examples of mini-grids types and ownership models

\begin{tabular}{|c|c|c|c|c|c|}
\hline $\begin{array}{l}\text { Ownership } \\
\text { model }\end{array}$ & Name of owner & $\begin{array}{l}\text { Mini-grid } \\
\text { type }\end{array}$ & Country & System size & Technology \\
\hline \multirow[t]{2}{*}{ Hybrid } & $\begin{array}{l}\text { Ngombeni Power Ltd } \\
\text { / TANESCO }\end{array}$ & Large & Tanzania & $1.5 \mathrm{MW}$ & Biomass \\
\hline & $\begin{array}{l}\text { Tangayika Wattle } \\
\text { Company Ltd. / } \\
\text { TANESCO }\end{array}$ & Large & Tanzania & $2.5 \mathrm{MW}$ & Biomass \\
\hline \multirow[t]{10}{*}{ Private } & Devergy & $\mathrm{DC}$ & Tanzania & $3 \mathrm{~kW}$ & Solar \\
\hline & Sincro Sitewatch & $A B C$ & Tanzania & Unknown & Unknown \\
\hline & Kirchner Solar & $A B C$ & Uganda & $22.5 \mathrm{~kW}$ & Solar \\
\hline & Carbon X & $A C$ & Tanzania & $11 \mathrm{~kW}$ & Solar \\
\hline & Husk power & $A C$ & Tanzania & $32 \mathrm{~kW}$ & Rice husk \\
\hline & $\begin{array}{l}\text { Kisiizi Power } \\
\text { Company }\end{array}$ & $A C$ & Uganda & $300 \mathrm{~kW}$ & Hydro \\
\hline & Remergy & $A C$ & Uganda & $5 \mathrm{~kW}$ & Solar \\
\hline & Powergen & $A C$ & Kenya & $1.4 \mathrm{~kW}$ & Solar \\
\hline & Powerhive & $A C$ & Kenya & $20 \mathrm{~kW}$ & Solar \\
\hline & $\begin{array}{l}\text { Andoya Hydro Electric } \\
\text { Power Company }\end{array}$ & Large & Tanzania & $1.2 \mathrm{MW}$ & Hydro \\
\hline \multirow[t]{3}{*}{ Community } & $\begin{array}{l}\text { Urambo Village } \\
\text { Cooperative }\end{array}$ & $A C$ & Tanzania & $180 \mathrm{~kW}$ & Diesel \\
\hline & Community of Thiba & $A C$ & Kenya & $135 \mathrm{~kW}$ & Hydro \\
\hline & $\begin{array}{l}\text { Cooperative in } \\
\text { Kitonyoni }\end{array}$ & $A C$ & Kenya & $13.5 \mathrm{~kW}$ & Solar \\
\hline
\end{tabular}

Source: author's own elaboration. 
The examples listed in Table 3 are described in detail below.

\section{Hybrid ownership}

The only type of mini-grid identified with hybrid ownership is large mini-grids. There are no known examples of village mini-grids using this ownership structure. This does not, however, conclude that such systems do not exist. ABC mini-grids, as will be shown later, are implemented purely through a private ownership model.

\section{Hybrid large mini-grids}

Ngombeni Power Ltd, Mafia Island, Tanzania, is an example of a large mini-grid with a hybrid ownership model. The production unit is a biomass unit, namely a steam turbine running on coconut wood privately owned by a company called Ngombeni Power Ltd. The distribution grid is owned and managed by TANESCO. Installed capacity is $1.5 \mathrm{MW}$, and the company sells power at $11 \mathrm{kV}$ to the national utility TANESCO at $\$ 0.301 / \mathrm{kWh}^{54}$.

The forestry product company Tangayika Wattle Company Ltd (TANWAT), Tanzania, commissioned in 1995, is another example of a large mini-grid with hybrid ownership. TANWAT produces power using waste wood from production and has an installed capacity of $2.5 \mathrm{MW}^{55}$. In addition to power generation for its own consumption, the plant sells surplus power to the Njombe/TANESCO-owned mini-grid through a power purchase arrangement (PPA) with TANESCO covering $1.4 \mathrm{MW}^{52}$.

\section{Private ownership}

The private ownership model is the most diverse model, and all four types of minigrids are seen implemented through it.

\section{Private DC village mini-grids}

This type of mini-grid represents a small part of installed systems.

Devergy is a Tanzania-based private company which started installing a solar PV mini-grid system in 2012 in the pilot village of Matipwili ${ }^{56}$. By October 2014 Devergy had electrified six villages with a total installed capacity of $18 \mathrm{~kW}$ (F. de Pascale, personal communication, November 2014). The mini-grid systems consist of connected individual solar panels with an associated battery for storage and a meter for each household that can be charged using prepaid electricity cards via mobile phones (ibid.).

\section{Private ABC mini-grids}

ABC mini-grids are purely operated through the private ownership model. However, this does not rule out subsidies or donor support. On the contrary, donor-supported initiatives have been launched in all three countries to develop the private market for the ABC model within the telecom sector.

Sincro Sitewatch Ltd. is a privately owned Tanzanian company with majority Tanzanian shareholding. As its core business it maintains and fuels approximately 800 telecom towers in Tanzania using conventional diesel generators. According to their CEO, the company is in the process of changing from being solely a power maintenance subcontractor to being an energy service provider ${ }^{57}$. In the village of Mgera, the company has connected households and the school to the network, with support from the World Bank. Surplus electricity from the telecom station is used by rural customers.

Kirchner Solar, Uganda, is piloting the ABC model as a new market segment in Kabunyata village, Luwero district, with support from GIZ. Kirchner Solar has installed solar containers with a capacity of $22.5 \mathrm{~kW}$ and acts as an energy services provider for both the telecom operator and private households ${ }^{58,59}$. 
African Solar Designs, Kenya, has recently received a seed grant under the joint IFCGSMA “Green Power for Mobile” program* to provide renewable power to an Airtel base station and to electrify a nearby community though a mini-grid for businesses and an energy kiosk for households to access charging and solar products ${ }^{60}$. The seed grant and the project is functioning as a pilot to generate lessons about ABC mini-grid business opportunities for private companies.

No detailed information is available about the outcomes of these ABC mini-grid projects in the literature.

\section{Private AC village mini-grids}

Carbon Energy X, in collaboration with the international renewable energy company Juwi, has installed an 11 kW PV-Module mini-grid serving 250 households in Masurura, Tanzania ${ }^{61,62}$.

Husk Power Systems is an India-based company with a total of 200 installed minigrids (25-100 kW) serving 325 villages in India, Nepal, Uganda and Tanzania ${ }^{63}$. According AECF (2014), Husk Power Systems has installed five $32 \mathrm{~kW}$ rice husk biomass gasifiers in Tanzania. However, no detailed information about the company's East African operations is available.

The Kisiizi hydro-powered mini-grid is owned by Kisiizi Hospital Power Ltd, a subsidiary of Kisiizi Hospital, a private missionary hospital administered by the Church of Uganda ${ }^{65,66}$. The power station, with a capacity of $300 \mathrm{~kW}$, was commissioned in $2009{ }^{66}$. The power from the station is used by the hospital and its affiliated institutions, and its surplus is sold to the wider Kisiizi community, including businesses and private homes. The number of connections by 2012 was $300{ }^{67}$.

Remergy, a Denmark-based company established in 2014, has so far installed one solar PV mini-grid in Kayanza village in Uganda. The mini-grid is a $5 \mathrm{~kW}$ system that provides electrical power to 120 households and businesses for the primary purpose of electrical lighting ${ }^{68}$. Remergy is, according to their website, preparing the implementation of similar systems in more off-grid villages (ibid.).

Powergen, Kenya, a Nairobi-based company, has implemented and owns four minigrids in the Masaai Mare area in Kenya with a capacity of $1.4 \mathrm{~kW}$ each. Financing for the mini-grids was raised through the online crowd-funding source Kiva ${ }^{69}$. Powergen has in total installed more than twenty mini-grids in Kenya however most of them are owned by others.

Powerhive, Kenya, was founded in 2011. Although headquartered in the USA, operations are run from the regional office in Nairobi. They have installed and own four mini-grids of a total of $80 \mathrm{~kW}$ in the vicinity of Kisii ${ }^{70}$ and is currently planning to upscale with hundred new sites (R. Wuts, personal communication, November 2014).

\section{Private large mini-grids}

According to Adebayo et al. ${ }^{71}$ and Msofe ${ }^{72}$, Andoya Hydro Electric Power Company has installed a 1.2 MW hydro-powered mini-grid in Mbinga, Mtambazi Tanzania (Ruvuma). Data availability and information about this project is very scarce, but according to Greacen the commercial operation of the plant was set for early $2015^{40}$. There is no documentation confirming that this mini-grid has become operational.

\footnotetext{
${ }^{*}$ Promoted in partnership with the Netherlands Ministry of Foreign Affairs, the use of green power such as solar and wind at mobile network towers in remote, rural areas around the world.
} 


\section{Community Ownership}

The main type of community-owned mini-grid is the AC village mini-grid. There are no accounts of any community-owned DC village mini-grids.

\section{Community-owned village AC mini-grids}

The Urambo Electric Consumers Co-operative Society (UECCO), Tanzania, was set up in 1993. UECCO owns, operates and manages the Urambo Power plant, which consists of three diesel gensets with a total installed capacity of $278 \mathrm{~kW}$. By 2005 approximately 2000 people were being served through UECCO ${ }^{28}$.

The community of Thiba, Kenya, has initiated its own hydro project, partly in cooperation with a local NGO GPower, and has been running the $135 \mathrm{~kW}$ hydroelectricity mini-grid through a cooperative since 2005, with $180 \mathrm{HH}$ connected ${ }^{32}$.

As part of it Energy for Development project, the University of Southampton has implemented a $13.5 \mathrm{~kW}$ mini-grid in Kitonyoni, Kenya. The mini-grid is owned and operated by a local cooperative ${ }^{73}$.

\section{Symbolic Community Ownership}

As already mentioned, information and data available about ownership models is in many cases scarcely available. It is therefore often challenging to determine the actual ownership of community-based mini-grids, and the prevalence of this ownership model is therefore unknown. However, one example of a case where community ownership is vaguely defined in the literature is the Mpeketoni Electricity project in Kenya. This is a dieselpowered mini-grid (initially $60 \mathrm{KVA}$, but later, with the addition of two generators, a total of $207 \mathrm{KVA}$ ) that began electricity production in 1994. Since then the mini-grid has been increased to a capacity of $960 \mathrm{~kW}^{74}$. Kirubi et al. present a well-documented analysis of the link between energy access and development from an empirical study of the Mpektoni minigrid ${ }^{30}$. The mini-grid in the study is referred to as community-based, though without giving an actual account of the legal ownership arrangements. According to ${ }^{75}$ the Mpeketoni minigrid is owned by the government and operated and managed by KPLC. According to ${ }^{76}$ it was "handed over to the community in 2004", which could indicate that there was a change in ownership and/or management structure in 2004. However, documentation is scarce, and the mini-grid may well have been owned by the community from the beginning or have a shared ownership structure (hybrid ownership) involving both the community and the government.

With reference to the point made earlier, regarding how the real ownership of assets deserves greater attention than they are currently receiving, it is worth noting how the term "community-based" is used descriptively without defining what it refers to. "Communitybased" could in this case either refer to the typology of the mini-grid (that it is an AC village mini-grid) or to the ownership structure (that it is community owned).

\subsection{Policy environment and planned mini-grids}

In terms of government support for mini-grids, all three countries are highlighting them as an important area of development ${ }^{77-79}$.

\section{Tanzania}

In the Scaling-up Renewable Energy Programme (SREP) investment plan for Tanzania ${ }^{77}$, it is anticipated "that mini-grids will be developed mostly in areas where there 
are one or more anchor commercial clients and/or TANESCO (that can be the buyer/seller of bulk power in conjunction with the renewable energy generation supplying the mini-grid) able to justify the bulk of the generation investment" (Reference 77, p. 56). This expectation is reflected in the electrification targets, where 25 large mini-grids with a capacity of $1.8 \mathrm{MW}$ each are planned.

In addition to the large mini-grids, fifty village-sized mini-grids are planned (ibid.). Furthermore, all eight SPP projects on isolated grids with either signed SPPA or LOI by 2013 were in the range between $300 \mathrm{~kW}$ and $7.5 \mathrm{MW}^{77}$.

The Tanzania Energy Development and Access Project (TEDAP), which was launched by the REA in 2011 with funding from the World Bank, has an off-grid component with three sub-components. First sub-component is the small power producer programme, which supports grid-connected renewable energy projects, grid-connected mini-grids and isolated mini-grids up to $10 \mathrm{MW}$. The second sub-component is Stand-alone Renewable Energy Electrification (using SHS and solar institutional systems) under which falls the "Sustainable Solar Market Package" (SSMP) model, which bundles institutional systems with household electrification services; and the Cluster model, where market aggregation is achieved by working with local associations such as coffee, cashew and tea smallholder associations. The third sub-component is the "Lighting Rural Tanzania" competition ${ }^{77}$.

On the regulation side, the current legal framework in Tanzania removes barriers for developers up to $10 \mathrm{MW}^{35}$. The Ministry of Energy and Minerals (MEM) has established simplified procedures for private-sector investment in solar, wind and micro-hydro projects, including a $100 \%$ depreciation allowance in the first year of operation ${ }^{80}$. Also, SPPs operating on an isolated mini-grid generating less than $1 \mathrm{MW}$ are not required to apply for a license and wait for approval from the regulator: a simple registration with the regulator suffices. Furthermore, for very small power producers (VSPPs) with an installed capacity of $100 \mathrm{~kW}$ or less, there is no requirement for regulatory review or approval of proposed retail tariffs (ibid.). On that basis, Tenenbaum et al. argue that Tanzania has "made more progress than any other African country in developing a comprehensive SPP regulatory system" (Reference 35, p.22 ).

When it comes to private-sector engagement, two US-based multinational corporations are involved in developing grid-connected mini-grids in Tanzania. Symbion, in partnership with KMR Infrastructure, is developing a biomass project in Kigoma that will replace diesel-based power for an existing TANESCO mini-grid. The signed PPA is for 3.3 MW, and commissioning was scheduled for December $2014{ }^{54}$. However, there are no accounts of the status of the project. The other company, called NextGens, is preparing a 5 MW power plant supplying power to 150,000 rural HH through a PPA with TANESCO in Kigoma District, Tanzania. Commissioning is scheduled for January $2015^{54}$. Similarly, there are no accounts of the current status of the project.

\section{Uganda}

Very little information is available about planned mini-grids in Uganda. The Rural Electrification Strategy Plan (RESP) from 2012 (covering 2013-2022) specifically prioritises rural electrification through PV-powered mini-grids. However, the goal of reaching 140,000 additional off-grid installation service connections by 2022 includes both individual $\mathrm{HH}$ systems and mini-grids, and hence no specific targets are outlined for mini-grids ${ }^{78}$. Although initiatives to support mini-grid initiatives have been taken (World Bank's Energy for Rural Transformation (ERT) programme) ${ }^{81}$, alongside the Promotion of Renewable Energy and Energy Efficiency Programme (PREEEP) implemented by MEMD and GIZ ${ }^{82,83}$, no information is available about the nature of these systems. 
In 2011, the rural electrification sector received a 13 million Euro grant from the Dutch ORIO Infrastructure Fund for the development, construction and operation of ten hydro mini-grids of up to $1.5 \mathrm{MW}$ each ${ }^{84,85}$. The total capacity of the ten mini-grids is 6.2 $\mathrm{MW}$, and some of the mini-grids will be connected to the main grid ${ }^{84}$. The project is still in the development phase (ibid.).

\section{Kenya}

In Kenya, the government's rural electrification master plan from 2008 focuses on the retrofitting of existing diesel-based decentralised power stations in the form of hybrid schemes with solar PV and wind, which, according to Gichungi ${ }^{86}$, is motivated by a wish to reduce operating costs. This refitting is being pursued through international donor support from the World Bank's Scaling-Up Renewable Energy Program (SREP), which aims to install $3 \mathrm{MW}$ of (PV and wind) in hybrid with the existing diesel generators in twelve isolated grids with a total installed capacity of $11 \mathrm{MW}^{79}$. In addition, currently fifteen mini-grids in the range of between $334 \mathrm{~kW}$ and $840 \mathrm{~kW}$ are under construction, and 44 sites have been identified for installing hybrid mini-grids. These are in the range between 284 and $1.3 \mathrm{MW}$ and have a total capacity of 17.8 MW. According to AHK, these mini-grids are being installed to add capacity in order to cover electricity demand in towns that have grown along with population and economic activities, and are hence not contributing additional rural electrification ${ }^{87}$. The UNEP lead programme entitled "Clean energy hybrid mini-grids in remote areas: an investment opportunity?" is seeking through demonstration projects to test and prove business models for replication ${ }^{37}$. The programme focuses on systems with a capacity greater than $100 \mathrm{~kW}$. The latest flagship publication from the Frankfurt School is focusing on refitting mini-grids with capacity sizes of $0.8 \mathrm{MW}$ to $9.5 \mathrm{MW}^{88}$.

\section{Discussion and conclusion}

The review of current and planned mini-grid interventions in East Africa undertaken in this paper shows that mini-grids have become a catch-all phrase with many meanings. The term mini-grid is used to cover a broad range of systems ranging from a few $\mathrm{kW}$ up to 10 MW, which masks the fact that the purpose of these systems varies. An overview of the combinations of ownership models and mini-grid types in East Africa identified in this paper is provided in Figure 1.

\section{[Insert Figure 1 here]}

Large mini-grids are implemented through utility ownership, hybrid ownership or private ownership models and are all characterised as supplying electricity to places with a large customer base and high levels of productive activity. As a means of increasing rural energy access, large mini-grids can therefore be discarded, as they do not supply electricity to remote rural populations. The particular mini-grids appropriate for the purpose of rural electrification are AC village mini-grids, whether privately owned or community owned, as well as ABC mini-grids and DC village mini-grids.

When analysing government and donor initiatives through the framework presented in Section 3.1, it becomes clear that, although village-size mini-grids have a place in rural 
electrification targets and plans, large mini-grids feeding into either the national grid or existing utility-driven mini-grids are given a high priority by governments and donors.

In Tanzania, in both the SREP and the TEDAP programmes, most initiatives are targeting large mini-grids. Specific programmes, targeted at what in this paper are called village-sized mini-grids, are limited to the "Sustainable Solar Market Package", the Cluster Model and the "Lighting Rural Tanzania" competition.

In Kenya, the government and donor support to large mini-grids is even more prominent than in Tanzania. All fifteen mini-grids under construction are large mini-grids, as are eight out of ten existing mini-grids where hybridisation is being proposed. Furthermore, the 44 sites identified for future development lie in the capacity range of $179 \mathrm{~kW}$ to $1.3 \mathrm{MW}$, with the majority of systems $>300 \mathrm{~kW}$. Kenya, through its portfolio of mini-grids, is specifically working towards expanding mini-grid systems in towns where demand is growing due to population growth and increasing productive activities ${ }^{87}$.

In Uganda, although information is sparse, Bena ${ }^{89}$ stresses that mini-grids are being targeted at areas that are far from the grid but have concentrated loads, such as trading centres and islands communities. Also, at least five of six government-owned mini-grids are larger than $300 \mathrm{~kW}$ (ibid).

Although large mini-grids can be expected to contribute with additional connections and hence increase electricity access, these new connections will be in towns and not in rural areas. Large mini-grids represent a very different business case compared to village sized mini-grids, with better investment opportunities being secured due to the predictable cash flows made possible with high demand and predictable consumption patterns, and with operations resembling utility operations in respect of technical operation, management structures, financing requirements and bankability.

The literature review carried out in this paper and the discussion above show that, although the term "mini-grid" covers a variety of systems in terms of technical features and organisational models, no specific language is available to differentiate between these systems in a systematic manner. This lack of a specific language with which to describe variations of mini-grids systems may present a barrier to increasing our understanding of the challenges to scaling up rural energy access through various organisational models as well as to creating appropriate policy measures. The framework developed in this paper might be useful in overcoming these barriers.

Based on the discussion above, we can also conclude that in East Africa there is currently a contradiction between the discourse that proposes mini-grids as a solution for delivering rural energy access and current country-level activities prioritising large-scale mini-grids delivering power to large towns. The notion of the mini-grid has become what David Mosse has called a mobilizing metaphor ${ }^{90}$. It is an inclusive notion, which, due to its blurred definition and positive connotations regarding rural electrification, is used to mobilize funding to provide green electricity to larger towns.

\section{Status and current trends for mini-grids for rural electrification}

Community-owned AC village mini-grids, and to some extent privately owned AC village mini-grids, have in the past been the only types of mini-grids implemented for rural electrification. Community-owned AC village mini-grids have been and still are implemented through donor funding by NGOs and universities. However, when looking across the three mini-grid types appropriate for rural electrification, a trend toward increased private-sector involvement is emerging, with DC village mini-grids being the least prominent of the three. Only one privately owned DC village mini-grid has been identified in this study. Although this seems to suggest this type of mini-grid to be of lesser importance it would be premature to reject the potential of this solution. DC village mini-grids do not support productive uses. 
However, they do represent an important effort to provide power for low load services such as lighting and mobile phone charging which are the primary demands in large parts of rural Sub-Saharan Africa ${ }^{91}$. It is a solution that, in load potential, is comparable to SHSs and could therefore be seen as an appropriate transitionary solution in areas where local demand does not include productive loads.

The ABC mini-grid as a means to increase rural energy access is a relatively new phenomenon in Africa. Although delivering electricity to rural populations is part of the business model, the primary target end-users for the ABC mini-grid are anchor clients. The rationale behind the business model of $\mathrm{ABC}$ mini-grids is to ensure steady revenues from an anchor client, whereas providing energy access to those living near the anchor client is a secondary priority. ABC mini-grids with telecom towers as anchor customers have, according to Hankins et al., great potential in increasing energy access in rural communities ${ }^{92}$. However, the impact with regard to rural energy access will depend on how the company implementing $\mathrm{ABC}$ mini-grids sets priorities between the (C)ommunity, the (A)nchor customer and the local (B)usinesses.

Especially in Kenya, a growing private sector is delivering AC village mini-grid solutions. This currently emerging private sector is dominated by start-up small and mediumsize enterprises (SMEs) with a core business consisting in delivering rural energy access through business models that are highly reliant on ICT and smart technologies. This is a diverse group of companies, but common features include the fact that they are missiondriven, that rural energy access is their core business and that they are implementing AC village mini-grids. Furthermore, their goal is to deliver rural energy access at scale rather than on a project basis. They are developing business models with the purpose of scaling up in order to deliver electricity to a large quantity of consumers through many smaller mini-grids.

This trend towards increased private-sector involvement follows a general trend identified by Hansen et al. that is specific to the solar PV market in East Africa ${ }^{38}$. Although private-sector involvement is growing, there are no signs of a reduction in NGO- and donordriven community-owned mini-grids. As Hansen et al. also stress, in the past donor-driven initiatives in the SHS market in Kenya have played an important role through experimentation and piloting, which contributed to maturing the private sector ${ }^{38}$. Donordriven community-owned mini-grids could serve the same purpose of delivering knowledge and market information and hence contribute to maturing the private market.

\section{Future research suggestions}

The fact that village-size mini-grids are particularly appropriate in the context of rural electrification, combined with the general expectation of private-sector involvement in driving the up-scaling of rural electrification, make privately owned AC village mini-grids a fruitful avenue for further investigation. One area for future research would therefore be empirically based analyses of concrete business models that pursue the dual objective of creating a social impact through the delivery of electricity and making a profit. A number of such private companies are developing AC village mini-grids in Kenya. However, very little is known about the performance of these private business models. Currently private-sector implementation of village-size mini-grids is at an early stage, and business models are still in the piloting phase. No private company has so far been able to scale up its operations. It is therefore unknown whether these private business models will be able to contribute to increasing rural energy access figures on a larger scale. This situation leaves policy makers in a void with respect to research-based policy recommendation.

Against this background, it seems timely and appropriate to address the challenges of diffusion of private-sector business models for rural electrification at three different levels. 
At the society social level, the diffusion of privately owned mini-grids could be analysed from an innovation system perspective, according to which the privately owned mini-grid is seen as a socio-technical innovation. One option in this regard would be to apply the multilevel perspective (MLP) as developed by Geels ${ }^{93}$. This perspective would permit a focus on the wider framework conditions for creating a viable niche for private-sector minigrids while at the same time being sensitive to the role of networks and learning across multiple actors in the mini-grid sector. Also, by conceptualising private mini-grid developers as a new niche, insights could be revealed about the processes through which private companies are acting as niche builders and possibly about how this knowledge could be used to support such processes elsewhere.

At the private company level, it is expected that companies will enter the market for rural electrification through for-profit business models, but there is also reason to believe that privately owned AC village mini-grids will be implemented by highly mission-driven companies who seek to balance social and economic value creation in developing and managing their business models. Insights into how this dual mission is balanced and managed are essential for the practical results on the ground, not least for the long-term sustainability of the business models. Insight into these issues can be gained by drawing on perspectives from the social entrepreneurship literature ${ }^{94}$.

At the village level, rural electrification interventions are not inserted into a void, but rather encounter a complex social reality ${ }^{95}$. It might therefore be a fruitful avenue to analyse private-sector interventions in rural villages through the perspective of the actor-oriented approach ${ }^{96,97}$, which allows the processes and dynamics at the interface between the private company and the recipients of electricity to be captured. Through this perspective, an intervention is viewed as an ongoing, socially constructed and negotiated process, and not simply as the execution of an already specified plan of action with controllable outcomes ${ }^{96}$. This perspective could thus reveal insights about the role of existing structures, interests and conflicts in the arena where the electrification system is situated and provide explanations for the resulting challenges for the company. 


\section{References}

1. IEA. World Energy Outlook 2011. Energy for All: Financing Access for the Poor. Paris: OECD/IEA; 2011.

2. Ondraczek J. Are we there yet? Improving solar PV economics and power planning in developing countries: The case of Kenya. Renew Sustain Energy Rev. 2014;30:604615. doi:10.1016/j.rser.2013.10.010.

3. $\quad$ ARE. Hybrid Mini-Grids for Rural Electrification: Lessons Learned. Brussels: Alliance for Rural Electrification (ARE); 2011.

4. Palit D, Chaurey A. Off-grid rural electrification experiences from South Asia: Status and best practices. Energy Sustain Dev. 2011;15(3):266-276. doi:10.1016/j.esd.2011.07.004.

5. Palit D, Sarangi G. Renewable Energy-Based Rural Electrification: The Mini-Grid Experience from India. Copenhagen: Global Network on Energy for Sustainable Development (GNESD); 2014. Available at: http://www.unepdtu.org/PUBLICATIONS. Accessed January 7, 2015.

6. Krithika PR, Palit D. Rural Electrification Through Decentralised Off-Grid Systems in Developing Countries. (Bhattacharyya S, ed.). London: Springer London; 2013. doi:10.1007/978-1-4471-4673-5.

7. Thirumurthy N, Harrington L, Martin D. Opportunities and Challenges for Solar Minigrid Development in Rural India. Denver: National Renewable Energy Laboratory (NREL); 2012. Available at: http://www.nrel.gov/docs/fy12osti/55562.pdf. Accessed January 7, 2015.

8. Pereira MG, Sena JA, Freitas MAV, Silva NF Da. Evaluation of the impact of access to electricity: A comparative analysis of South Africa, China, India and Brazil. Renew Sustain Energy Rev. 2011;15(3):1427-1441. doi:10.1016/j.rser.2010.11.005.

9. Millinger M, Mårlind T, Ahlgren EO. Evaluation of Indian rural solar electrification: A case study in Chhattisgarh. Energy Sustain Dev. 2012;16(4):486-492. doi:10.1016/j.esd.2012.08.005.

10. Schnitzer D, Lounsbury DS, Carvallo JP, Deshmukh R, Apt J, Kammen DM. Microgrids for Rural Electrification : A Critical Review of Best Practices Based on Seven Case Studies. United Nations Foundation; 2014.

11. Bhattacharyya SC. Viability of off-grid electricity supply using rice husk: A case study from South Asia. Biomass and Bioenergy. 2014;68(0):44-54. doi:10.1016/j.biombioe.2014.06.002.

12. Bhandari AK, Jana C. A comparative evaluation of household preferences for solar photovoltaic standalone and mini-grid system: An empirical study in a costal village of Indian Sundarban. Renew Energy. 2010;35(12):2835-2838. doi:10.1016/j.renene.2010.05.006.

13. Bhandari V, Adhikary B, Dahal R, Maskey RK, Shrestha N. Socioeconomic aspects of Nepalese Mini-Grid. In: 2nd International Conference on the Developments in Renewable Energy Technology, ICDRET 2012.Vol Dhaka. Bangladesh; 2012:367-369. Available at: http://www.scopus.com/inward/record.url?eid=2-s2.084860563164\&partnerID=tZOtx3y1.

14. Blum NU, Bening CR, Schmidt TS. An analysis of remote electric mini-grids in Laos using the Technological Innovation Systems approach. Technol Forecast Soc Change. 
2015;95:218-233. doi:10.1016/j.techfore.2015.02.002.

15. Ulsrud K, Winther T, Palit D, Rohracher H, Sandgren J. The Solar Transitions research on solar mini-grids in India: Learning from local cases of innovative socio-technical systems. Energy Sustain Dev. 2011;15(3):293-303. doi:10.1016/j.esd.2011.06.004.

16. Zerriffi $\mathrm{H}$. Innovative business models for the scale-up of energy access efforts for the poorest. Curr Opin Environ Sustain. 2011;3(4):272-278.

doi:10.1016/j.cosust.2011.05.002.

17. Krithika PR, Palit D. Participatory Business Models for Off-grid Electrification. In: Bhattacharyya S, ed. Rural Electrification Through Decentralised Off-Grid Systems in Developing Countries. Green Energy and Technology. London: Springer London; 2013:187-225. doi:10.1007/978-1-4471-4673-5.

18. Nygaard I, Dafrallah T. Utility led rural electrification in Morocco: combining grid extension, mini-grids, and solar home systems. Wiley Interdiscip Rev Energy Environ. 2015;3:n/a-n/a. doi:10.1002/wene.165.

19. Kammen DM, Kirubi C. Poverty, energy, and resource use in developing countries: focus on Africa. Ann N Y Acad Sci. 2008;1136:348-57. doi:10.1196/annals.1425.030.

20. Kemausuor F, Obeng GY, Brew-Hammond A, Duker A. A review of trends, policies and plans for increasing energy access in Ghana. Renew Sustain energy Rev. 2011;15(9):5143-5154.

21. Bhattacharyya SC. To regulate or not to regulate off-grid electricity access in developing countries. Energy Policy. 2013;63:494-503. doi:10.1016/j.enpol.2013.08.028.

22. Haanyika CM. Rural electrification in Zambia: A policy and institutional analysis. Energy Policy. 2008;36(3):1044-1058. Available at: http://www.sciencedirect.com/science/article/B6V2W-4RGVWJ31/2/95b5791dcbfb19c1da051f82a3d370f7.

23. Bazilian M, Nussbaumer P, Gualberti G, et al. Informing the Financing of Universal Energy Access: An Assessment of Current Financial Flows. Electr J. 2011;24(7):5782. doi:10.1016/j.tej.2011.07.006.

24. Bhattacharyya S. Financing Electrification and Off-Grid Electricity Access Systems. In: Bhattacharyya S, ed. Rural Electrification Through Decentralised Off-Grid Systems in Developing Countries. Green Energy and Technology. Springer London; 2013:227252. Available at: http://dx.doi.org/10.1007/978-1-4471-4673-5_9.

25. Szabó S, Bódis K, Huld T, Moner-Girona M. Energy solutions in rural Africa: mapping electrification costs of distributed solar and diesel generation versus grid extension. Environ Res Lett. 2011;6(3):034002. doi:10.1088/1748-9326/6/3/034002.

26. Kaijuka E. GIS and rural electricity planning in Uganda. J Clean Prod. 2007;15(2):203-217. doi:10.1016/j.jclepro.2005.11.057.

27. Baldwin E, Brass JN, Carley S, MacLean LM. Electrification and rural development: issues of scale in distributed generation. Wiley Interdiscip Rev Energy Environ. 2015;4(2):196-211. doi:10.1002/wene.129.

28. Ilskog E, Kjellström B, Gullberg M, Katyega M, Chambala W. Electrification cooperatives bring new light to rural Tanzania. Energy Policy. 2005;33(10):1299-1307. doi:10.1016/j.enpol.2003.12.006.

29. Eder JM, Mutsaerts CF, Sriwannawit P. Mini-grids and renewable energy in rural 
Africa: How diffusion theory explains adoption of electricity in Uganda. Energy Res Soc Sci. 2015;5:45-54. doi:10.1016/j.erss.2014.12.014.

30. Kirubi C, Jacobson A, Kammen DM, Mills A. Community-Based Electric Micro-Grids Can Contribute to Rural Development: Evidence from Kenya. World Dev. 2009;37(7):1208-1221.

31. Werner C, Breyer C. ANALYSIS OF MINI-GRID INSTALLATIONS: AN OVERVIEW ON SYSTEM CONFIGURATIONS. In: 27th European Photovoltaic Solar Energy Conference, 24-28 September 2012, Frankfurt, Germany ANALYSIS; 2012:24-28.

32. Yadoo A, Cruickshank H. The role for low carbon electrification technologies in poverty reduction and climate change strategies: A focus on renewable energy minigrids with case studies in Nepal, Peru and Kenya. Energy Policy. 2012;42:591-602. doi:10.1016/j.enpol.2011.12.029.

33. SE4ALL. High Impact Opportunity (HIO). Clean Energy Mini-grids. 2014. Available at: http://www.se4all.org/wp-content/uploads/2014/08/MinigridsHIO.pdf. Accessed June 22, 2015.

34. ARE. Rural Electrification with Renewable Energy: Technologies, Quality Standards and Business Models. Brussels: Alliance for Rural Electrification (ARE); 2011.

35. Tenenbaum B, Greacen C, Siyambalapitiya T, Knuckles J. From the Bottom Up: How Small Power Producers and Mini-Grids Can Deliver Electrification and Renewable Energy in Africa. Washington DC: World Bank; 2014. Available at: http://elibrary.worldbank.org/doi/abs/10.1596/978-1-4648-0093-1. Accessed February 16, 2015.

36. Kempener R, Lavagne d'Origue O, Saygin D, Skeer J, Vinci S, Gielen D. Off-Grid Renewable Energy Systems: Status and Methodological Issues. Abu Dhabi: The International Renewable Energy Agency (IRENA); 2015. Available at: http://www.irena.org/DocumentDownloads/Publications/IRENA_Offgrid_Renewable_Systems_WP_2015.pdf.

37. Cooper D. Clean Energy Hybrid Mini-Grids in Remote Areas - an Investment Opportunity? UNEP; 2014. Available at: http://www.microgrid-news.com/pdf/UNEPMini-Grids-Info-Sheet.pdf. Accessed January 20, 2015.

38. Hansen UE, Pedersen MB, Nygaard I. Review of solar PV policies, interventions and diffusion in East Africa. Renew Sustain Energy Rev. 2015;46:236-248. doi:10.1016/j.rser.2015.02.046.

39. Todd B. DC microgrids: a new source of local power generation? Renew Energy Focus. 2009. Available at: http://www.renewableenergyfocus.com/view/3199/dcmicrogrids-a-new-source-of-local-power-generation/. Accessed November 25, 2014.

40. Greacen C. Mini-Grid Systems on the Rise in Tanzania Status of Implementation and Regulatory Framework Conditions.; 2014.

41. Franz M, Perterschmidt N, Rohrer M, Kondev B. Mini-Grid Policy Toolkit: Policy and Business Frameworks for Successful Mini-Grid Roll-Outs. Eschborn: EUEI-PDF; 2014.

42. Wollny M, Hermes M. Ac coupled hybrid systems and mini grids. In: ANZSES Solar 07. Alice Springs; 2007:1-8.

43. GSMA. Powering Telecoms: West Africa Market Analysis. 2013. Available at: 
http://www.millennia2015.org/files/files/Zero_mothers_die/gpm_market_analysis_wes t_africa_.pdf. Accessed June 23, 2015.

44. UNEP. Increasing Private Capital Investment into Energy Access: The Case for MiniGrid Pooling Facilities. UNEP; 2015.

45. Hazelton J, Bruce A, MacGill I. A review of the potential benefits and risks of photovoltaic hybrid mini-grid systems. Renew Energy. 2014;67:222-229. doi:10.1016/j.renene.2013.11.026.

46. Gunaratne L. Rural Energy Services Best Practices. Prepared for United United States Agency for International Development Under South Asia Regional Initiative for Energy; 2002.

47. Frame D. Community Rural Electrification and Development. Community Rural Electrification and Development (CRED), University of Strathclyde; 2011.

48. Bhattacharyya S. Rural Electrification Through Decentralised Off-Grid Systems in Developing Countries. London, Heidelberg, New York, Dordrecht: Springer London; 2013. doi:10.1007/978-1-4471-4673-5.

49. Ilskog E. And Then They Lived Sustainably Ever After? - Part 1, Experiences from Rural Electrification in Tanzania, Zambia and Kenya. 2005.

50. Boubou P, Watchueng S, Masse R. Public-Private Partnerships in Rural Electrification Programs in Africa. Group of African Agencies and Structures in charge of Rural Electrification (Club-ER); 2010. Available at: http://www.cluber.org/gb/upload/DOC251.pdf.

51. ECA. Project Design Study on the Renewable Energy Development for Off-Grid Power Supply in Rural Regions of Kenya Project. London: ECA (Economic Consulting Associates Limited); 2014.

52. Uisso JP. Rural Energy Agency and Innovation in Delivery of Modern Energy Services to Rural Areas. 2012. Available at: http://www.esmap.org/sites/esmap.org/files/4b. TANZANIA_Innovation in Delivery of Services.pdf. Accessed September 15, 2014.

53. Yadoo A, Cruickshank $\mathrm{H}$. The value of cooperatives in rural electrification. Energy Policy. 2010;38(6):2941-2947. Available at:

http://www.sciencedirect.com/science/article/pii/S0301421510000558.

54. Greacen C. Tanzania’s Small Power Producer (SPP) Program. IFC Investment Climate Infrastructure Workshop on Small Power Producers. 2013.

55. HEDON. TANWAT Biomass Electricity Tanzania: HEDON Household Energy Network. Biomass Based Electr Prod TANWAT Case Study, Tanzania. 2014. Available at: http://www.hedon.info/TANWATBiomassElectricityTanzania. Accessed October 31, 2014.

56. Devergy. Devergy - Developing Energy. 2014. Available at: http://www.devergy.com/the-plan/. Accessed May 13, 2014.

57. Sincronicity Power Ltd. Sincronicity Power Ltd - Sincro Sitewatch Ltd. 2012. Available at: https://www.youtube.com/watch?v=GYqgFYg7E94. Accessed September 15, 2014.

58. Kurz K. The ABC-Modell Anchor Customers as Core Clients for Mini-Grids in Emerging Economies.; 2014. 
59. REA. Report on the Consultative Meeting Held in Respect of the Application for License Exemption by Kirchner Solar. Rural Electrification Agency (REA) Uganda.; 2014.

60. GSMA. Mini-Grids : Reducing Risks and Costs through the Anchor Customer Business Model.; 2014.

61. Jochem F. Mini-grid Implementation. Experience as an EPC Contractor. 2013.

62. World Bank. The Potential for Alternative Private Supply (APS) of Power in Developing Countries. 2014;(June).

63. USAID. Private Sector Partners. Priv Sect Partners. 2015. Available at: http://www.usaid.gov/powerafrica/partners/private-sector\#hu. Accessed April 29, 2015.

64. AECF. Husk Power Systems. Funding Innov Bus Africa. 2014. Available at: http://www.aecfafrica.org/windows/react/projects/husk-power-systems. Accessed October 9, 2014.

65. Schäfer M, Kebir N, Philipp D, Martina Schäfer, Noara Kebir DP. Micro Perspectives for Decentralized Energy Supply. In: Martina Schäfer, Noara Kebir DP, ed.

Proceedings of the International Conference. Berlin; 2011:1-2. Available at: http://www.tu-berlin.de/microenergysystems.

66. Kisiizi Hospital Power Ltd. Kisiizi Electricity. 2014. Available at: http://www.kisiizihospital.org.ug/?page_id=89. Accessed January 19, 2015.

67. Kisiizi Hospital Power Ltd. Annual Report for 2012. Kisiizi Hospital Power Ltd.; 2013.

68. Remergy Energy Solutions. Kayanza micro-grid. 2015. Available at: http://remergy.com/news!/kayanza-micro-grid.aspx. Accessed January 27, 2015.

69. PowerGen Renewable Energy. Nkoilale Micro-Grid. 2014;June. Available at: http://powergen-renewable-energy.com/portfolio-item/community-nkoilale-microgrid/. Accessed January 27, 2015.

70. Powerhive East Africa Ltd. Services: microgrid operations management. Powerhive. 2015. Available at: http://www.powerhive.com/services/. Accessed January 27, 2015.

71. Adebayo E, Sovacool BK, Imperiale S. It's about dam time: Improving microhydro electrification in Tanzania. Energy Sustain Dev. 2013;17(4):378-385. doi:10.1016/j.esd.2013.03.003.

72. Msofe BH. RURAL ENERGY ACCESS THROUGH OFF-GRID RENEWABLES by Director for Technical Services Contents of Presentation. 2009.

73. Energy for Development. Kitonyoni Solar Power Plant, Kenya. 2014. Available at: http://www.energyfordevelopment.net/projects-2/kitonyoni/. Accessed January 19, 2015.

74. Gichungi H. Mini-grid PV Business Opportunities in Kenya. 2013. Available at: http://www.giz.de/fachexpertise/downloads/2013-en-gichungi-pep-workshop-pvkenia.pdf. Accessed October 14, 2014.

75. Camco, UNDP, Parliament C. Mini-Grid Toolkit Field Study Report for Kenya , Mozambique and Zambia. Camco; 2010.

76. Kinyanjui DM, Kituku PM. Mpeketoni Electricity Project. Nairobi; 2006. Available at: http://www.globalelectricity.org/Projects/RuralElectrification/Nairobi/Day- 
2_fichiers/Case Study Mpeketoni Electricity Project.pdf. Accessed January 28, 2015.

77. GoT. Scaling-up Renewable Energy Programme (SREP) Investment Plan for Tanzania April 2013. Dar Es Salaam: Government of Tanzania (GoT); 2013. Available at: https://www.climateinvestmentfunds.org/cif/sites/climateinvestmentfunds.org/files/SR EP_Tanzania_Investment_Plan_Design.pdf.

78. GoU. The Government of the Republic of Uganda: Rural Electrification Strategy and Plan, Covering the Period 2013-2022. Government of Uganda (GoU); 2012. Available at: http://rea.or.ug/phocadownload/rural electrification strategy and plan 20132022.pdf.

79. GoK. Scaling up Renewable Energy Program (SREP) Investment Plan for Kenya. Government of Kenya (GoK); 2011. Available at: http://www.climateinvestmentfunds.org/cifnet/sites/default/files/Kenya SREP Investment Plan - Endorsed.pdf.

80. Bauner D, Sundell M, Senyahwa J, Doyle J. Sustainable Energy Markets in Tanzania Report I: Background. Stockholm: Stockholm Environment Institute; 2012. Available at: http://www.renetech.net/?portfolio=renewable-energy-market-development-studytanzania.

81. Hankins M, Saini A, Kirai P. Uganda's Solar Energy Market. Target Market Analysis. Berlin: Deutsche Gesellschaft für Technische Zusammenarbeit (GTZ).; 2009.

82. PREEEP. Small Scale Hydropower Schemes. 2015. Available at: http://www.energyprogramme.or.ug/small-hydro-power-2/. Accessed January 28, 2015.

83. GIZ. Renewable energy and energy efficiency. 2015. Available at: https://www.giz.de/en/worldwide/19268.html. Accessed January 28, 2015.

84. Rijksdienst voor Ondernemend Nederland. Mini Hydropower \& Rural Electrification Project. 2011. Available at: http://www.rvo.nl/subsidies-regelingen/projecten/minihydropower-rural-electrification-project. Accessed January 28, 2015.

85. IED. Support Study for DFID. Low Carbon Mini Grids: "Identifying the Gaps and Building the Evidence Base on Low Carbon Development.” Innovation Energie Dévelopment (IED); 2013. Available at:

https://www.gov.uk/government/uploads/system/uploads/attachment_data/file/278021/ IED-green-min-grids-support-study1.pdf. Accessed January 28, 2015.

86. Gichungi H. Mini Grid PV Business Opportunities in Kenya. Presentaion; 2013. Available at: http://www.giz.de/fachexpertise/downloads/2013-en-gichungi-pepworkshop-pv-kenia.pdf. Accessed February 13, 2015.

87. AHK. Target Market Study Kenya Solar PV \& Wind Power. Nairobi: AHK Delegation of German Industry and Commerce in Kenya; 2013.

88. Frankfurt School - UNEP Collaborating Centre. Renewable Energy in Hybrid MiniGrids and Isolated Grids: Economic Benefits and Business Cases. Frankfurt School UNEP Collaborating Centre for Climate and Sustainable Energy Finance; 2015.

89. Bena B. The Role of Mini-Grids in Increasing Electricity Access in Uganda. Rural Electrification Agency (REA) Uganda.; 2014.

90. Mosse D. Is good policy unimplementable? Reflections on the ethnography of aid policy and practice. Dev Change. 2004;35(4):639-671. Available at: C:Documents and SettingslivnylMy Documents\litteraturlethnography of aid david mosse.pdf. 
91. Jacobson A. Connective Power: Solar Electrification and Social Change in Kenya. World Dev. 2007;35(1):144-162. doi:10.1016/j.worlddev.2006.10.001.

92. Hankins M, Saini A, Kirai P. Kenya’s Solar Energy Market: Target Market Analysis. Berlin: Deutsche Gesellschaft für Technische Zusammenarbeit (GTZ); 2009.

93. Geels F. Technological transitions as evolutionary reconfiguration processes: A multilevel perspective and a case-study. Res Policy. 2002;31:1257-1274.

94. Doherty B, Haugh H, Lyon F. Social Enterprises as Hybrid Organizations: A Review and Research Agenda. Int J Manag Rev. 2014:1-20. doi:10.1111/ijmr.12028.

95. Nygaard I. Institutional options for rural energy access: Exploring the concept of the multifunctional platform in West Africa. Energy Policy. 2010;38(2):1192-1201.

96. Long N. Development Sociology: Actor Perspectives. Taylor and Francis; 2003.

97. Olivier de Sardan J-P. Anthropology and Development: Understadning Contemporary Social Change. London and New York: Zed Books; 2005.

\section{Figure 1. Mini-grid types implemented through four ownership models}

Source: author's own elaboration. 